Coville, Frederick V.

Botany of Yakutat Bay, Alaska 


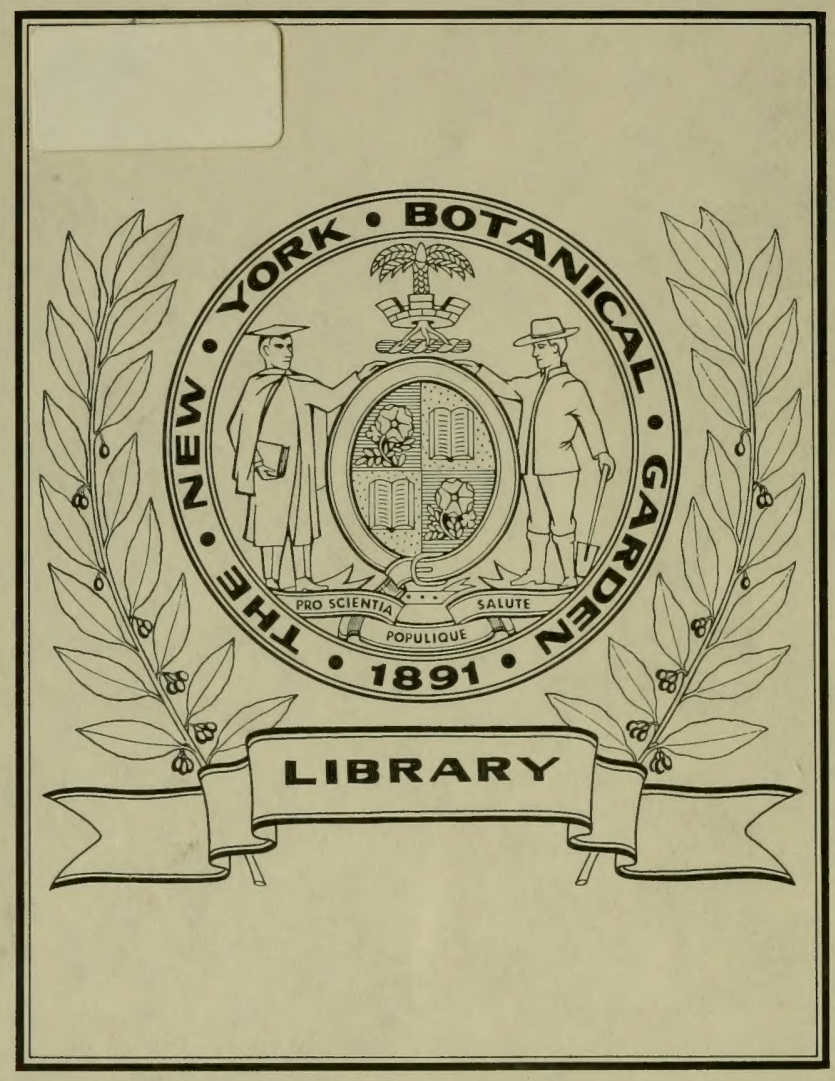




\section{U. S. DEPARTMENT OF AGRICULTURE.} DIVISION OF BOTANY.

\section{CONTRIBUTIONS}

From

\section{THE U. S. NATIONAL HERBARIUII.}

Vol. III, No. 6.

ISSUED JANUARY 15, 1896.

BOTANY OF YAKUTAT BAY. ALASKA.

By FREDERICK VERNON COVILLE.

\section{WITH A FIELD REPORT}

By FREDERIOK FUNSTON.

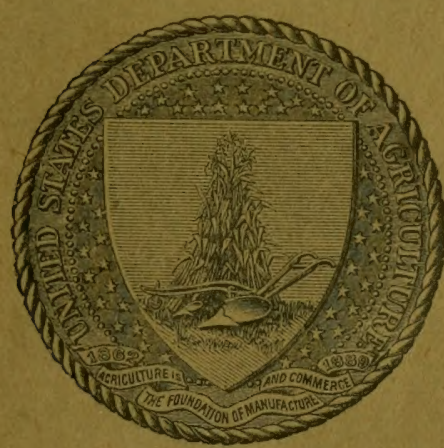

WASHINGTON:

GOVERNMENT PRINTING OFFICE. 1895 . 

U. S. DEPARTMENT OF AGRICULTURE. DIVISION OF BOTANY.

\section{CONTRIBUTIONS}

FROM

\section{THE U. S. NATIONAL HERBARIUII.}

Vol. III, No. 6.

ISSUED JANUARY 15, 1896.

BOTANY OF YAKUTAT BAY, ALASKA.

BY FREDERICK VERNON COVILLE.

WITH A FIELD REPORT

BY FREDERICK FUNSTON.

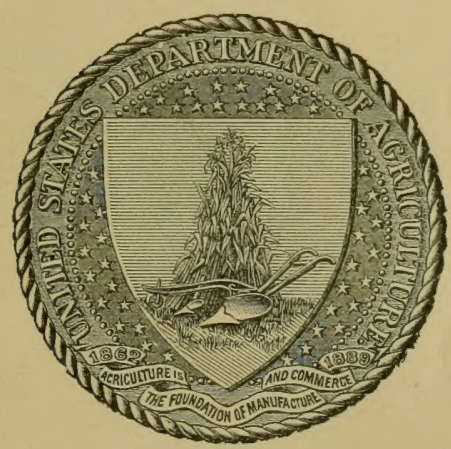

WASHINGTON:

GOVERMMENT PRINTING OFFICE.

1895. 
$Q K 195$
.$C 68$

1896 


\section{LETTER OF TRANSMITTAL.}

\section{U. S. Departient of Agriculture, \\ DIVISION OF BOTANY, Washington, D. C., August 21, 1895.}

SiR: I have the honor to transmit herewith, for publication as Volume III, No. 6, of Contributions from the United States National Herbarium, a manuscript entitled "Botany of Yakutat Bay, Alaska." This paper constitutes a report on the botany of one of the obscure parts of our country, and is a result of the explorations of a field agent of this Department, Mr. Frederick Funston, during the summer of 1892.

Respectfully,

\section{Frederick V. Coville,}

Botanist.

Hon. J. Sterling Morton, Secretary of Agriculture.

\section{TABLE OF CONTENTS.}

I. Field report. By Page.

II. Botanical report. By Frederick Vermon Cor

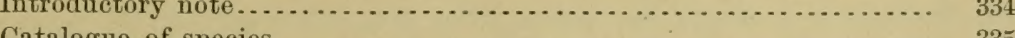

Catalogue of species....................................... 335

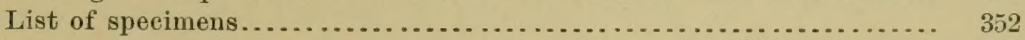

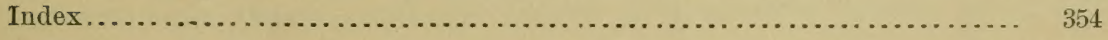





\section{BOTANY OF YAKUTAT BAY, ALASKA.}

\section{I.-FIELD REPORT.}

By Frederick Funston.

In accordance with my commission and letter of instructions to proceed to Yakutat Bay, Alaska, and make a collection of the plants of that vicinity, I took passage from San Francisco on the Coast Survey steamer Hassler, having purchased a camp outfit and hired a laborer to accompany me on the trip as cook and general camp employee. The Hassler sailed April 16, 1892, and on her way north touched at Port Townsend, Victoria, Departure Bay, Port Simpson, and Sitka, arriving at Yakutat Bay May 19, after a voyage of thirty-three days. On the night following our arrival there arose a heavy southeasterly wind, accompanied by rain, which continued with great violence for five days; so that it was not until May 25 that I was able to establish my camp on shore. In order to have some place suitable for storing supplies and earing for specimens, I rented from the natives a house situated in the smaller of their two villages, on Khantaak Island; the larger village being on the mainland, distant abont a mile.

The Iudians, of whom about two hundred live in the vicinity of Yakutat Bay, belong to the Thlinket tribe and are uncivilized, though apparently well disposed toward white people who come among them. They live in rude houses of their own construction, and subsist mostly on fish, both fresh and smoked, shellfish, crabs, and other marine animals, besides the flesh and oil of the hair seal. Seal oil seems to be their staff of life, as it is eaten with nearly ali kinds of food, both animal and vegetable. During the summer season the Indians use large quantities of berries, and also utilize several edible plants, to be mentioned hereafter.

Immediately on establishing my camp I began the work of collecting, though at this season but few plants were in flower. I endeavored to obtain twenty sheets of dried specimens of each species, but in some cases only a partial series could be secured on account of the scarcity of the plant. The drying papers were changed two or three times every day and dried by hand over a fire before they were returned to the presses, this work being rendered necessary by the great humidity of the atmosphere and the almost daily rains. During the season about 10 cords of wood were used in keeping up these fires. 
Yakutat Bay and the land in its immediate vicinity may be briefly described as follows: The bay, which lies approximately in latitude $60^{\circ} \mathrm{N}$. and longitude $140^{\circ} \mathrm{W}$., not only extends through the narrow strip of lowland separating the St. Elias range of mountains from the ocean, but also penetrates the range itself for a considerable distance. Its width at the entrance, between Ocean Cape on the east and Point Manby on the west, is about 20 miles, and its length, from the capes to the entrance of Disenchantment Bay, about 30 miles. The latter bay is merely an extension of Yakutat Bay, and lies wholly within the St. Elias range, being walled in by tremendous mountains rising from the water's edge. Its length is about 25 miles, and its width from 3 to 5 miles. Great glaciers composed of pure ice several hundred feet in thickness extend down to the water and throw off large numbers of icebergs, which crowd the waters of the bay at all times and are carried by the tides iuto Yakutat Bay, lining its western shore as far as Point Manby, the prevailing southeasterly winds holding them against this shore. The largest of the glaciers on Disenchantment Bay are the Hubbard and Dalton, the former having a frontage on the water of 6 miles and the latter of 2 miles, and each being about 15 miles long.

Beginning again at the entrance of Yakutat Bay, and following its eastern shore line from Ocean Cape to the foothills of the St. Elias range, a distance of about 20 miles, the surface of the country is generally level, though in some places there are hills 50 feet high. About 2 miles from Ocean Cape the Ankow River, a sluggish stream a hundred yards wide, empties into the bay. The Ankow has not been explored, but the Indians give its length as about 20 miles. As the country through which it flows has but little elevation above the sea, the waters of this river are extremely brackish as far as 7 miles from its mouth, being affected by the sea water at high tide. Between the mouth of the Ankow and the foothills of the mountains a number of small treshwater streams reach the waters of the bay. After the foothills of the range are reached the entire surface of the country undergoes a radieal change, becoming extremely broken and mountainous, with numerous very rapid streams. In this region there is very little level land, the mountains genierally rising from the beach to far above the line of perpetual snow. The most conspicuous peak in this locality is Mount Tebenkof, elevation unknown. Proceeding farther north, up the bay, the mountains become more precipitous and the snow line gradually comes nearer to sea level, until at the entrance to Disenchantment Bay the country has a decidely Arctic character. It is on this latter bay that the great glaciers appear, and in some sheltered eanyons snow is found at sea level even in midsummer. Crossing the upper end of Yakutat Bay to the west side, near the mouth of Dalton Creek, the country is generally ievel, sloping gradually upward toward the mountains. In this vicinity a number of wide gravel washes, eut up by numerous small streams, come down from the neighboring mountains. 
From the mouth of Dalton Creek to P'oint Manby, a distance of 30 miles, the narrow strip of land, less than a mile wide, lying between the beach and the edge of the Malaspina Glacier, is a succession of sand dunes near the beach and of gravel ridges near the glacier, with here and there small streams formed by the melting of the glacier ice.

On the easteri side of Takutat Bay are about a dozen small islands, ranging in size from Khantaak, 7 miles long, to some less than an acre in extent.

During the first three weeks following my arrival, I collecterl on Kilhantaak Island and on the adjacent mainland from the Mission to Ocean Cape, aud also took a canoe trip to Mr. Me(irath's camp, on the opposite side of the bay near Point Manby, a distance of 20 miles, but found little here that I had not ahearly collected. Several days of the latter part of June were spent on a trip by sea to the base of Mount Teben. liof, a distance of 18 miles, but the weather was such that little was accomplished. A canoe trip to the mainland near Knight Island about the middle of July was more sucessful, though I was rompelled by a heavy rain storm to return after a stay of one day. Several other journeys were made by canoe during the sumner whenever the weather would permit, and nearly every accessible point on the shores of the bay was visited. It hat been my original intention to spend the greater part of the summer at I )alton's cabin, an abandoned house in the forest, 3 miles from the beach on the west side of the bay near its hearl; but a dense ice jack which lay oft' this shore nearly all the summer prechded any attempt to effect a landing.

On Angust 2, accompanied by my laborer and another man employed toassist in handling the canoes in the ice, I left Khantalk Islaud with two canoes containing my eamp out fit, collecting apparatus, and provisions for a two weeks' cruise, visiting nearly every part of Disenchuntment Bay and climbing many of the momntains on its shores to the line of perpetual snow. The greater part of ny collections in this region were made on the sonthern shore of the bay, near the large rock known as Haenke Island. Canoeing in Disenchantment Bay was attended with much labor and no little peril, as we rere constantly in danger of being crushed in the floating ice which filled the bay at nearly all times.

On A ugust 14, while camper on the east side of Disenchantment Bay near its entrance, I noticed that the ice floe off the mouth of Dalton Creek seemed to be less densely packed than nsual, and, loading both canoes, I crossed to the oplosite side and succeded in landing, though one of the canoes was upset in the surf. Two days later I returned to Khantaak Island with my entire outtit. During this two weeks' trip the weather was exceptionally favorable and the collections were the most satisfactory made during the season. The rain poured in torrents nearly every day during the Jatter half of Angust, though some collecting was done in the intervals. The rainfall is said to have been 
heavier in the summer of 1892 than in any other since the American oceupation of Alaska. From my arrival at Yakutat Bay on May 19 until my departure on September 4, a period of 107 days, there were but 24 days wholly without rain.

The plant life of the region about Yakutat Bay is characterized by the dense and vigorous growth of a comparatively suall number of species, giving the forests especially an appearance of great sameness.

The almost level country lying on the eastern side of the bay, between Ocean Cape and the foothills of the mountains, is covered with a forest growth practically impenetrable. The great amount of fallen timber, together with the tangled and heavy undergrowth, constitnte such obstacles to travel that even the Iudiaus, who have lived here many years, have never penetrated the forests of the mainland for a mile from their own village. The great bulk of this forest is composed of the Sitka spruce (Picea sitchensis), which in this region reaches a height of 70 feet. This tree extends from sea level to an altitude of 2,200 feet on the sides of Mount Tebenliof; but as one follows the coast line up the bay from this monntain, the upper limit becomes lower and lower, until at the entrance of Disenchantment Bay it reaches sea level, the tree not being found on the shores of this bay. A large forest lies along Dalton Creek, and there are several of considerable extent between this place and Point Manby.

The timber of the spruce tree plays a most important part in the economy of the natives, as from it are constructed their houses and canoes, and it is used in the manufaeture of oil crates, bows, arrows, and other implements, while the smaller roots, after being boiled and split, are used in basket weaving.

The hemlock (T'suga mertensiuna) is found scattered throngh the spruce forests, and seems to have about the sime vertical range as that tree, but is much less abundant and is somewhat smaller in size. The only other conifer foumd in this vicinity was a single individual of Sitlia cypress (Chomecyporis noothutensis), a small tree on Khantaak Island near the Iudian village.

The rel alder (Almus rubra) is found in great quantities throughout the forest region, especially on the edges of open glades, along the banks of streams, near the beach, and on the mountain sides, above the limit of spruce. On the westem slope of Momut Tebenliof it reaches an altitude of 3,000 feet, s00 feet higher than spruce and hemlock, and grows on these higher slopes in such dense jungles as to be almost impenetrable, constituting one of the most serious obstacles to moun. tain climbing in this region. On the shores of Disenchantment Bay, where the spruce is not found, the alder reaches an altitude of 800 feet. This tree is also fomd in large quantities along the western shore of the bay.

A willow (Salix barclayi), growing from 5 to 10 feet high, is found sparingly on Khantaak Islaud and in the low forest region, and is abundant in the wide canyons and washes of the St. Elias range and 
along the numerous small streans flowing from the Malaspina glacier, where it forms dense thickets which are the favorite resort of the ptarmigan.

The elder (Sambucus racemosa), an elect shrub about $S$ feet in height, is common but not abundant in the open, well-drained tracts near the margin of the forest, more especially on Khantakk Island and near the mouth of the Ankow River. The bright, red berry ripens abont the 1st of September, but as I left the country about this time I can not say whether the natives use this fruit or not.

Menziesia ferruginea, an erect shrub from 4 to 6 feet high, which flowers during the first half of June, is scattered throngh the denser forests. The highest altitude at which this plant was found was 1,800 feet above the sea on the sides of Mount Tebenkor, where, on June 22, the buds were not yet open.

The high-bush cranberry (Tiburnum panciflorum) is common in the forest region, growing more abundantly aloug the margins of the glates than in the dense woods. The blossons are open in early June. The fruit-a bright scarlet berry about the size of a pea-is ripe after. August 20 and is highly prized by the natives, who use large puantities in season but do not preserve it for winter consumption.

The blueberry (I'acinium ovalifolium), a shrub 4 feet in height, forms a large part of the forest undergrowth in the low comntry, but is not found at any cousiderable altitude. The fruit, a dark pmple berry larger than a pea, is collected in great ruantities by the natives, who not only use it in season but preserve it for wiuter, drying the crusherl berries by artificial heat. It is considered an important article of food, and in September, immediately after the close of the fishing season, nearly all the women and children of the village begin collecting and drying a supply for the coming winter.

Rubus spectubilis, lnown ail along the northrest coast as the salmon berry, a spreading bush from 4 to 6 feet in height, grows in immense guantities in the less densely shaded forests and along the beach. It reaches an altitude of 2,200 feet on 1 lonut Tebenk of. At this place, however, the growth is much stunterl, as it is also on the sirles of a momutain above the entrance of Disenchantment Bay at an altitude of 1,100 feet. The fruit, which in general shape resembles the red rispberry, is abont an inch long by half an inch in diameter, and varies in color from very light to very dark red. It begius to ripen at sea level about August 5 , and at higher altitudes two weeks later. During the season it is an important artiele of food among the uatives, who gather large quantities in baskets. The berry is sometimes eaten as taken from the bush, but is usually crushed in a wooden bowl and eaten with seal oil. It is not preserved for winter use.

The devil's club (Echinopanax horridum), an erect shrub from 4 to 6 feet in height, with slender woody stem branching near the top, aud densely covered. with short, sharp prickles, is abundant in all the forests 
The other plants found on these sandy stretches are Lathyrus maritimus, which is very abundant; Arabis hirsuta, sometimes eaten raw by the Indians; Arenaria lateriflora, Castilleja miniata, Ranunculus nelsoni, Lupinus nootkatensis unalaskensis, Epilobium latifolium, Pneumaria maritima, Phellopterus littoralis, Rhinanthus crista-galli, Achillea millefolium, Gentiana amarella, Selinum gmelini, Pedicularis palustris utassoviana, and Juncoides campestre sudeticum.

Along the gravel beaches just out of reach of high ticle are found Glaux maritima, Arenaria peploides, Puccinellia maritimu, and Poa glumaris.

The mountaius of the St. Elias range in the Disenchantment Bay region, as has already been stated, are clothed to an altitude of about 800 feet with a deuse growth of Alnus mbra. There are, however, in some localities extensive breaks in these thickets which are well filled with other vegetation, whle there is a considerable variety of growth above the limit of this tree. A few of the plants in the viciuity of Disenchantment Bay have already been mentioned as occurring on Khantaak Island and on the mainland near the Mission, but the great majority of those collected in this region were not found in the low forest country. I3eginning at about the upper limit of the red alder, the mountain sides are covered with a heavy growth of grass, Deschampsia cerpitosa longiflora, to au altitude of 2,550 feet. These grassy slopes are in many places given a decidedly bluish tinge by the blossoms of the monkshood (Aconitum delphinifolium). Abore the grass limit the regetation is more scattering, and consists mostly of salix arctict, a willow about 3 inches in height; Saxifruga bronchiulis, Gerunium "rianthum, Cassiope stellerianu, Luethea pectinata, and Bryunthus glunduliflorus. The highest altitude which I reached on these mountains was 4,250 feet above the sea. At this height, at the time of my risit (the first two weeks of August), one reaches almost continuous snow fields, the mountains being unbroken white except where they are too steep for the suow to lie on, or where it has been swept arvay in an avalanche.

Among the plants collected in this treeless mountain region, besicles those already mentioned, were Tellima grandiflora, Arabis lyrate, which is eaten raw by the natives; Cerastium ulpinum, Pyrolu minor, Tuleviana sitchensis, Potentilla procumbens, I'arnussia fimbriatu, Artemisia norregica, Potentilla villosu, Barbavea burbarea, Ranunculus cooleya (veryrare), Antennaria alpina, Companula rotundifolia alastiuna, Tussilago firigida, Antenuaria margaritacen, Hierucium triste, Habenaria bractenta, Lycopodium alpinum, Anemone narcissiffora, Prenanthes aluta, Arpilegia formosu, Arnicu lutifoliu, Romanzoffu sitchensis, Euphrusia officinalis, Geum culthifolium, C'ryptofrumme acrostichoides, Cystopteris firagilis, Arrostis exarata, Phleum alpinum, and Poa alpina.

As has been stated at the beginning of my report, but little collecting was done after my return to Khantaak Island fiom Disenchantment 
Bay, on account of the weather, so that my work for the season was now practically closed.

The total number of specimens collected during the summer was about 3,000 , representing 154 different species.

The work of the coast survey parties having been completerl, the Hossler called in at Yakntat on September 3, and the next day started on her return to San Francisco. On account of a delay at Sitka and continued unfavorable weather, the ressel did not reach Port Townsend until October 3,1892 . As the time of the ship's departure for San Francisco from this port was uncertain, I left the vessel here and proceeded east.

In elosing, I wish to acknowledge my indebtedness to Captain Harber and other officers of the Hossler, and to Messrs. Micirath and Turner, of the United States Coast and Geodetic Survey, all of mhom took a lively interest in my work aud aided me in many ways. 


\title{
II.-BOTANICAL REPORT.
}

\author{
By Frederick Verson Coville.
}

INTRODUCTORY NOTE.

The excellent collection of plants brought by Mr. Funston from the vicinity of Yakutat Bay, Alaska, in 1892, gives us our first comprehensive knowledge of the flora of that locality. The specimens collected undoubtedly represent nearly all the species of vascular plants that occur in the area traversed, but circumstances prevented, for the most part, the collection of the cellular cryptogams.

Yakutat Bay is an interesting point in the classification of the zonal plant areas of the Pacific Coast, for at this place the dense coastal forest characteristic of the coast monntains of British Columbia and sonthern Alaska is broken by the occurrence of a series of glaciers which here come down to the very beach, counteracting the influence of the warm ocean eurrents and driving the timber line back ward into the sea. Westrard from Yakutat Bay such breaks are frequent as far as Cooks Inlet and the eastern part of Kadiak Island. ${ }^{1}$ West of these points the coniferous timber of the coast region ceases. ${ }^{2}$

On the west side of Yakutat Bay the Malaspina Glacier prevents the growth of trees except at a few sheltered points. The forest on the east side of Yakutat Bay, from Ocean Cape to Mount Tebenkof, a distance of about 30 kilometers, is described by Mr. Funston as dense and impenetrable and extending inland for an unknown distance. Of snch a nature is the coastal forest which extends almost uninterruptedly to Sitka and still farther south.

The trausition ground of such a change from forest to perpetual snow and ice is full of interest. One stretch of it lies on the eastern shore of Yakutat Bay, from Mount Tebenk of to the point which marks the entrance of Disenchantment Bay, on the east. Following up the eastern shore of Yakutat Bay over the lowlands, the forest meets Mount Tebenkof, the southermmost peak of this section of the St. Elias range, and asceurls it to an altitude, on its western slope, of 2,200 feet. From this point the timber line dips abruptly downward aloug the coastward

" "The eastern part of Kadiak Island and those lying to the mortheast of it are abundantly supplied with spruce and other trees." Contributions to the Natural History of Alaska, 1886, p. 16; l, L. M. Turuer. Arctic Series of Fublications, No. II, Signal Service, U. S. Army.

${ }^{2}$ See map in Alaska Coast Pilot, 1879, Appendix I, Meteorology and Bibliography; by W. H. Dall. 
slope of the mountains until at the month of Disenchantment Bay, about 20 kilometer's from Mount Tebenkof, it meets the sea.

The conditions which favor the northward progress of the forest are: The low elevation of the coast region, the warmth of the ocean currents, and the prevailing southeasterly winds; while the opposing conditions are: The higher elevation of the mountains, the snow and ice which cover them, and the occasional northerly winds.

Two zones are clearly represented in the flora of the Yakntat Bay region, one extending from the sea up to timber line, the other from timber line to the lower limit of perpetual suow. The conspicuous floral features of these zones are described by Mr. Funston in his field report. In its general geographie relationship the Yakutat liay flora shows an almost exchusively circmpolar origin, while in its differentiation from the circumpolar flora it conforms with that of Western British America and the mountains of Washington and Oregon.

The appended catalogne of the collection contains 137 species and varieties of vascular plants and 27 of cellular plants. The determmation of the specimens in certain cases has been made by students of special grouls, the name of each of whom is inserted in the proper place in the catalogie.

\section{CATALOGUE OF SPECIES.}

\section{RANUNCULACEAT.}

Anemone narcissiflora L. Sp. Pl. i, 542 (1753). Type localities, the Alps of Austria, switzerland, and siberia. The specifis: name, apparently hy a slip of tho pen, was printed tirst "nureissifolia," lut was corrected in al subseruent edition to narcissiflora.

Disenchantment Bay, August 13 (No. 114), nearly past flowering. The plant is abundant, ranging from 300 to 900 meters altitude.

Ranunculus cooleyæ Viasey \& Rose, Contr. Nit. Herh, i, 289 (1893). The typo specineus are those collected hy Miss Cooley near Junean, Alaskil, and those of the present collection.

On the summit of a monntain on the mainland sontheast of Haenke Islanr, Diyenchantment Bay, August 10 (No. 99), at an altitule of 1,000 meters. Only four plants were seen. I am wholly mable to agree with Professor E. L. Greene ${ }^{1}$ in considering this plant a close relitive of Fumlieniu hystriculu (Gray) (reene, which is the liununculus hystriculus of Gray. In that peculiar plant the sepals are petaloid, being large and white like those of an Anemone, while the petals are reduced to minute stalked nectaries. In Ranunculus cooleye the sepals are of an herbaceous green color, while tho petals have the large size, expauded form, and bright yellow color of an ordinary buttercup.

Ranunculus reptans L. Sp. Pl. i, 549 (1753); R. flammula reptans Meyer, PI. Labr. 96 (1830). Deseribed from specimens collected in Sweden aud Russia.

Khantaak Island, July 31 (No. 81), along the margin of a fresh-tvater marsh.

Ranunculus nelsonii (DC.), Gray, Proc. Amer. Acad. viii, $37 \pm$ (1873); R. recurvatus nelsonii DC. Syst. i, 290 (1818). The type specimens were collected on the island of Unalaska by David Nelson. 
Knight Island, June 18 (No. 29), on a treeless, sandy bliff. It was common on Khantaak Island, and a few specimens were found ou Mount Tebenkof at an altitude of 180 meters.

Caltha palustris L. Sp. Pl. i, 558 (1753). Type specimens from Europe.

On the east side of Yakutat Bay, near Ocean Cape, May 28 (No. 4); in the margins of fresh-trater lagoons, but not abundant.

Coptis trifolia (L.) Salisb. Trans. Linn. Soc. viii, 305 (1807); Helleborus trifolia L. Sp. Pl. i, 558 (1753). Type localities, vanada and Siberia.

Khantaak Island, June 3 (No. 11); found sparingly among mosses aud ferus in the lowlands.

Aquilegia formosa Fisch.; DC. Prodr. i, 50 (1753). Type locality, Kamchatka. Disenchantment Bay, August 14 (No. 121); abundant up to an altitude of 200 meters.

Aconitum delphinifolium DC. STst. i, 380 (1818). The type specimen was collected "in Hedge Island ad oras occidentales America borealis" by David Nelson.

Disenchantment Bay, August 13 (No. 116); abundant on the grassy slopes of the mountains from 275 to 750 meters altitude.

Actæa spicata arguta (Nutt.) Torr. Pac. R. Rep.iv, 63 (1857); A. arguta Nutt.; Torr. \& Gr. Fl. i, 35 (1838). The type locality is "woods of the Oregon [i, e., the Columbia] and its tributary streams."

Near the Mission, June 6 (No. 14); growing in treeless, sandy soil covered with grass.

\section{NYMPHAPACEX.}

Nymphea polysepala (Engelm.) Greene, Bull. Torr. Club, xr, 84 (1888); Nuphar polysepalum Engeln, Trans. St. Louis Acad. ii, 282 (1865). Type locality, the higher Rocky Mountains, from the sources of the Platte to those of the Columbia. The various stations known at that time were also given.

Khantaak Island, June 26 (No. 43), in a fresh-water pond abont 1 meter deep.

\section{BRASSICACE㘴.}

Barbarea barbarea (L.) MacMillan Met. Minn. Val. 259 (1892); Erysimum barbarea L. Sp. Pl. ii, 660 (1753); Larbarea kulgaris R. Br. in Ait. Hort. Kew. ed. 2, iv, 109 (1812). Type specimens from Europe.

Disenchantment Bay, August 8 (No. (5)); growing in damp, sharly spots from sea level to an altitnde of $\mathbf{1 2 5}$ meters.

Arabis hirsuta (L.) Scop. Fl. Carn. ed. 2, ii, 30 (1772); Turritis hirsuta L. Sp. PI. ii, 666 (1753). Original specimens, from Sweden, Germany, and England.

Khantaak Island, June 7 (No. 15); found abundantly abont an old Indian camp. For use, see page 332 .

Arabis lyrata L. Sp. Pl, ii, 665 (1753). Type specimen collected in Canada by Kalm.

Disenchantment Bay, August 3 (No. 84); common ou rock slides and all places where other vegetation is scarce, at an altitude of 150 meters or less.

Cardamine oligosperma Nutt.; Torr. \& Gr. Fl. i, 85 (1838). Type locality, "shady woods of the Oregon."

Khantaak Island, May 30 (No. 7); growing along the beach above tide water. Dr. N. L. Britton, to whom specimens have been submitterl, refers them to $C$. oligosperma, yet donbtfully, for they have no nature fruit. He says that they are certainly not C. hirsuta.

Draba stenoloba Ledeh. Fl. Ross, i, 15t (1842). The type specimens were collected on the island of Unalaska by Chamisso and Eschscholtz.

Disenchantment Bay, August 9 (No. 96); on the sides of a rocky cliff, 90 meters above the sea. These specimens are in some cases annuals, in others biennials or 
short-lived peremials, but they retain in tho latter caso a characteristic slenclerness of the persistent part of tho stem. Such specimens seldom ocenr in the Rocky Mountains and Siera Nevadi, but, aceording to Ledebour, a subperenuial habit is characteristic of the species.

\section{VIOLACEAE.}

Viola glabella Nutt.; Torr. \& (ir. Fl. i, 112 (1838). T5po locality, "sharly wookls of the Oregon," i. e., the Columbia River.

Near the entrance of Disenchantment Bay, July 24 (No. 74), on a mountain slope at the altitude of 125 meters.

Viola langsdorfii Fisch.; DC. Prodr. i, 296 (1824). 'Type locality, the island of Unalaski.

Khantaak Island, June 3 (No. 12) and June 27 (No. 48). No. 48 is a robust eanlescent plant with flowers, when not shrunken, 18 to $25 \mathrm{~mm}$. long. No. 12 has no welldeveloped aërial stems, and is a smaller plant than the other, with smaller flowers and more nearly glabrons petals. It blooms, Mr. Funston states, a month earlier than No. 48 and has flowers of a lighter blue. It will bo seen that its characters incline toward those of $Y$. pulustris. No. 12 is abuudant throughout the forest region, while No. 48 is said to occur less frequently.

\section{CARYOPHYLLACE开.}

Cexastium alpinum L. Sp. P'l, i, 438 (1753). 'Typo specimens from Ėurope.

Disenchantment Bay, August 3 (No. 85) occurriug but scantily.

Arenaria lateriflora L. Sp. Pl. i, 423 (1753). Type specimeus from Siberia.

Khantaak Island, June 12 (Nos, 18 and 19). Theso specimens, like others from the northern portions of the range of the species, are of low stature, seldom exceeding $10 \mathrm{~cm}$. in height, and have leaves about $1 \mathrm{~cm}$. in length. In No. 19 the anthers are nearly hlack aud contain a mass of bodies many times smaller than pollen grains, undoubtelly their atrophied and functionless representatives. The same tendeney towarl the suppression of the stamens is manifested in other herbarium specimens. The plant grew on a sand spit and aloug a saudy bluff.

Arenaria peploides I. Sp. Pl. i, 42:3 (1753). The Limnitan plants came from the seashores of northern Europe.

Khantaak Island, $J$ ume 20 (No. 37). All the Alaskan specimens in the National IIerbarium belong to the form described by Torrey and Gray as Honelienyu oblongifolia. The plant is strietly a littoral species, growing in profusion along gravelly beaches betreen the line of high tide and the forest. It is very commonly used to produce a smudge to drive away insects.

\section{PORTULACACEA.}

Claytonia sibirica L. Sp. Pl. i, 204 (1753). 'Type locality, Siberia.

At the base of Mount Tebenkof, Yakutat Bay, June 22, (No.42). The plant is abnudant along the banks of streams flowing into Disenchantment Bay. For use sue page 330 .

\section{GERANIACEA.}

Geranium erianthum DC. Prodr. i, 611 (1824). The species was decribed from specimens collected by David Nelson in Kamchatka and northwestern North America.

Disenchantment Bay, August 10 (No. 100); common on the slopes of the mountains from 550 to 900 meters.

$5076-\mathrm{No}_{0} 6$ - 2 


\section{FABACEAE.}

Lupinus nootkatensis unalaskensis Wats. Proc. Amer. Acal. viii, 524 (1873). The type specimens of this variety were collected on the Island of Unalaska.

Khantaak Island, June 20 (No. 35). It was found in abundance also in Disenchantment Bay and on the west side of Yakutat Bay. The National Herbarium contains specimens not ouly from Unalaska but also from the Shumagin Islands and Kadiak Island.

Lathyrus maritimus (L.) Bigelow, Fl. Bost. ed. 2, 268 (1824); Pisum maritimum I. Sp. Pl. ii, 727 (1753). First describer from European specimens.

At the month of the Ankow River, Yakutat Bay, June 13 (No, 20); abundant on a bare, sandy point.

Lathyrus palustris L. Sp. Pl. ii, 733 (1753). Type locality, Europe.

Khantak Island, July 27 (No. 77), in the margins of forest openings.

\section{ROSACETE.}

Luetkea pectinata (Pursh) Kuntze, Rev. (:en. Pl. i. 217 (1א!1); Naxifraga perfinata Pursh, Fl. i, 312 (1814). Type specimen, from the "northwest coast" of North America, collected by Menzies.

Disenchantment Bas, August 5 (No. 90); abundant in tho monntains, occurring between 180 and 1,200 moters altitude.

Fubus pedatus Smith, Ic. P1. Ined. t. 63 (1791). "In Americe borealis tractn occidentali legit Archibaldus Menzies."

Khantaak Island, June (No. 151); frequent in the moist spruce forests.

Rubus spectabilis P'ursh, F'l. i, 3.1\%, t. 11; (1814). I'ursh fleseriher the species from specimens collected by Lewis and Clarke on the banks of the Columbia River, and by Menzies "on the northwest coast."

At the Mission, May 26 (No. 1). For the distribution and uses of this plant, see page 329.

Rubus stellatus Smith, Ic. Pl. Inerl. t. 64(1791). 'Type locality the same as that of Rubus pedatus.

Near the Mission, June 1 (No.9); common in the damp woods of the lowlands.

Geum calthifolium Smith, in Rees, Crcl. xvi (1819). Type specimen, collected "by Mr. Menzies on the west coast of North America."

Near Dalton Landing, August 16 (No. 130), occurring on a monntain sicle at an altitude of about 250 meters.

Geum macrophyllum Willd. Enum. i, 557 (1809). Type locality, "in Camtschatca."

Khantaak Island, June 17 (No. 25); a common weed near a deserted Indian village.

Fragaria chiloensis (L.) Lam. Encycl. ii, 537 (1786); F. resen chiloensis L. Sp. Pl. i, 495 (1753). 'Type locality not given.

Khantaak Island, May 27 (No. 2). This plant has a thick, closely bracteate rootstock and thick, coriaceons leaves, glabrons and impressed-reticulate above, densely villous beneath, as in specimens from the vicinity of San Francisco. For the distribution and uses of this plant, sce page 331 .

Potentilla anserina L. Sp. I'l. i, 49.5 (1753). Tรpe locality Europe:n.

Near the Mission, June 19 (No. 34). The plant is common but is confined to the beaches, both on the islands and on the mainland. The leaf of Potentille anserina is one example of a type represented in the present collection by three other species, Fragaria chiloensis, Polentilla villosa, and Phellopterus littoralis. In all these plants the leaf is somewhat thickened, rugose and glabrous above, and beneath very densely tomentose or villous. All the species grow upon the naked, sandy beach of the ocean just above the line of high tide, where they are exposed not only to the 
moisture-laden air of the region, but to the direct rays of the hot, summer sun, and, probably also, to the iufluence of the salt water in the soil. The similarity in the leaves of these plants, in the light of their diversity in natural relationship and their subjection to the same enviromment, is strongr evidence of their adaptive modification for a common purpose.

Potentilla palustris (L.) Scop. Fl. Carn. ed. 2, i, 359 (1772); Comarum palustre L. Sp. Pl. i, 502 (1753). Type locality, Enropean.

Alonir the Ankow River, about 10 kilometers from the point where it empties into Yakutat Bay, July 16 (No.63); growiugr abumdantly in fresh-water swamps uear the stream.

Potentilla procumbens (I.,) Clairs. Mammel, 166 (1811); Sibbaldia mocumbens I. Sp. Pl. i, 284 (1753). Described from European specimens.

At Dalton Landing, August 15̆ (No. 12t). The species was nearly past flowering.

Potentilla villosa Pall.; 1'ursh, Fl. i, 353 (1814). Tho typo specimens, which Pursh saw in the herliarium of Lambert, came from the "northwest coast" of North America. In Ledebour's Flora Rossica tho recorderl American localities in which specimens were collected by l'allas aro tho islands of Katiak and Unalaska.

Foumd only at a fow points in Disenehantment 13ay, Augrust 8 (No.94) and August 10 (No. 103), from sea level to an altitude of 650 meters. At this timo the plant was nearly past flowering.

Sanguisorba latifolia nom. nov.; Somyismbu canudensis latifolia Hook. Fl. lior. Amer. i, 198 (1834); Sanguisorba sitchensis C. A. Meyer; 'Tranty. \& Moy. I. Ochot. 35 (1856); P'oterium sitchense VVats. Bibl. Ind. 303 (1878). 'The plant was described from specimens collected by Scouler at "Observatory Inlet, Northwest coast of America" and by Clamisso at Unalaska.

Along tho Ankow River, about 10 kilometers above its mouth, July 16 (No. 66), on the edges of sandy bluftis along the river bank.

Sorbus occidentalis (Wats.) Greene, Fl. F'xun.5t (1891); I'y/rus occidentalis Wats. Proc. Amer. Acad. xxiii, 263 (1888). The type specimens are from the higher woumtains of Washington, Oregon, and California.

Disenchantment Bay, August 5 (No.92). Only two specimens were seen, forming trees 2 to 3 meters high aud growing at an altitulo of 250 meters. Tho plant is referred to S. occidentalis with doubt; for while it has leaflets eutire for their lower half, like those of that species, its young shoots are clensely pubescent with brown hairs and the flowers art unusually large, the pretals reaching a length of 5 to $6 \mathrm{~mm}$, and the calyx-throat a brealth of $5 \mathrm{~mm}$. 'Thecpmes are 3 to $5 \mathrm{~cm}$. in diameter, and the leaflets nine to thirteen in number, the larger 5 an. loug. The plant is not referable to typieal S. sumbucifoliu:

\section{SAXIFRAGACEAE.}

Saxifraga bronchialis I. Sp. P1. i, 400 (1753). Type locality, Siberia.

Diseuchantment liay, August 5 (No.91) ; growing on the mountains at the altitude of from 575 to 1,150 meters. The leaves of this plant present the thick body and thin margins that occur also in Bryanthus glanduliflorus.

Saxifraga mertensiana Bong. Veg. Sitch. 141 (1831). Type locality Sitka.

At the base of Mount Tebenkof, June 22 (No. 41); abundant along the bank of a stream.

Saxifraga punctata L. Sp. PI. i, 401 (1753). Type locality, Siberia. At the base of Mount Tebenkof, June 22 (No. 40); growing with No. 41.

Saxifraga stellaris L. Sp. Pl. i, 409 (1753). 'Tỷpe locality European.

On the east side of Yakutat Bay, 25 kilometers north of the Mission, July 14 (No. 60); growing along a stream. The name S. stellaris is here used for this plant to emphasize the fact that, while conmonly referred to S. lencanthemifolia of Michanx, now S. michauxii Britton, it does not really belong to that species. The type locality 
of Michanx's plant is "in excelsis montibus Carolinie," and it has not been found outside the Alleghauy Mountains, although often collected there. European authorities have held that true $S$. stellaris has never been found in America, ancl that name is here adopted only for convenience.

Tiarella trifoliata L. Sp. Pl. i, 406 (1753). Type locality, uorthern Asia.

Khantaak Island, June 7 (No. 16), in the spruce forest.

Tellima grandiflora (I'ursh) R. Br.; Richards. Apl. Frank]. Jouru. 765 (1823); . IF tella grandiflora Pursh, Fl. i, 314 (1814). Describerl from specimens collected on the northrvest coast of North Ameriea by Menzies.

Disenchantment Bay, August 3 (No. 83); from sea level to an altitude of 150 meters.

Heuchera glabra Willd, livem. \& schult. Syst. vi, 216(1820). Type specimen collected by Pallas in the western part of North America.

On the east shore of Yakutat Bas, 25 kilometers north of the Mission, July 14 (No. 59), aloug a forest stream.

Parnassia fimbriata Banks; Koenig and sims, Ann. Bot. i, 391 (1805).

Disenchantment Bay, Augnst 5 (No. 88); abundant on the monntain slopes from 180 to 675 rneters of altitude.

Ribes laxiflorum I'ursh, Fl. ii, 731 (181t). The original specimens wre collected by Menzies "on the northwest coast."

On the east side of Yakutat Bay, near Ocean Cape, May 28 (No. 5).

The species occurs throughout the forest area in the vicinity of Yakutat Bay and is abundant on the foothills of the mountains. On Mount 'Tebenkof it extends to an altitude of 575 meters. The specimens are nearly past flowering. The use of the name Ribes americanum by Miller' for the plant commonly known as $R$, floridum pre-

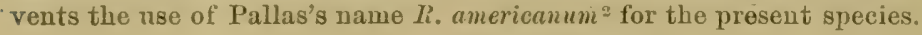

\section{ONAGRACE正.}

Epilobium latifolium L. Sp. Pl. i, 347 (1753). Type specimen from Siberia.

On the rest side of Yakutat Bay, about 7 miles north of Pount Manby, June 28 (No. 49), and at Dalton Landing, Angust 15 (No. 128). The petals in these specimens sometimes attain the length of $2.8 \mathrm{~cm}$. 'The petals, which are very beautiful and delicate, may bo described as of a purplish, but pale, rose color. No. 128 is an albino. The species occurred aloundantly ou the west sile of Yakutat Ijas, between the beach and the moraine of the Malaspina Glacier; and alongr the base of Mount Tebenkof, occasionally rising to an altitude of nearly 500 meters.

Epilobium luteum P'ursh, F1. i, 259 (1814). Type specimen from the "northwest coast" of North America, collected by Pallas.

On the eastern side of Yakutat Bay, about 25 kilometers north of the Mission, July 14 (No.58); growing along the beach just above the line of high tide. $\Lambda$ few specimens were seen aiterwards in the same situation in Disenchantment Bay.

Epilobium palustre L. Sp. Pl. i, 348 (1753). Type specimen from Europe.

Near the Mission, July 30 (No. 80); found in but one place. The filiform, subterranean offishoots characteristic of this species are excellently shown in some of the specimens. Like the similar slemler organs of Circur alpina, thej are rell adapted, in this exceediugly moist climate and in the moist, loose stratum of moss, leaves, or light soil through which they push their way, to propagate the plant without the loss of strength incilent to a greater outlay of regetative tissue. In a drier climate or a barder soil. much stouter and better protected structures, and consequently a greater expenditure of vital energs, would be required to accomplish the same result.

Circea alpina L. Sp. Pl.i, 9 (1753). Type specimen from Europe.

At the mouth of Diseuchantment Bay, July 21 (No. 76), amung the rocks along the beach. 


\section{AMMIACE王。}

Cicuta virosa L. Sp. Pl. i, 255 (1753). Type specimen from Europe.

Khantaak Island, July 22 (No.71); common in the edges of treeless openings.

Phellopterus littoralis Schmidt, Fl. Sachal. 138 (1868).

Along the Ankow near Ocean Cape, July I (No.51). It occurred only among the sand dunes aloug the river and on the beach.

[Not before reported from Alaska. J. N. Rose.]

Ligusticum scothicum L. Sp. Pl. i, 250 (1753). Type localities, the seaslores of England and Sweden.

Ocean Cape, July 18 (No. 70), on bluffs near the beach.

Selinum gmelini (Cham. S Sehlecht.) Kurtz in Engler, Bot. Jarb. xix. 3x'- (1\$94); Ligusticum gmelini Cham. \& Schlecht. Linnere, i, 391 (1826); Selinum benthami Wats. Bibl. Ind. 432 (1878). Type specimens from Alaska.

Cape Phipps, July 23 (No. 73), on a sandy beach near the edge of the forest.

Cœlopleurum gmelini (D('.) Lesleh. Fl. Ross. ii, stil (181.4); Arehangeliru ymelini DC. Prodr.ir, 170 (1830). Type specimens from Kamchatka.

Khantaak Island, June 26 ( $\mathrm{No} .44$ ); abundant in sunuy spots about a deserted Indian village.

Heracleum lanatum Michx. Fl. i, 166 (1803). 'Type locality, Canada.

Khantaak Island, June 26 ( No. 45); abundant on both the island and the mainland, growing along the margins of the forests and in their openings, and extending far up into Disenchantment Bay. For uso as food, seo page 331.

\section{ARALIACE 压.}

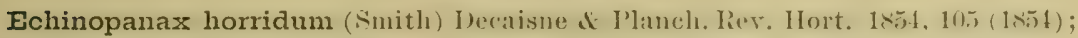
Panax horridum Swith, in Rees, Cycl, xxvi (1819). Typo specimen collected by Míuzies at Nootka Sound, Vancouver Island.

Khantaak Island, August 30 (No. 143), with mature fruit. 'Tho plant, which is popularly known as "devil's elub," in May and $J$ nne bears clusters of white, sweet-scented flowers. It is very common in the woods from sea level to an altitude of 550 meters, and its thick stems, from 0.5 to 2 meters high, covered with stout, spine-like prickles, often render one's progress difficult and painful. It occurs throughout the lowland forests in the vicinity of Yakutat Bay, following them to the altitule of 550 meters on Mount T'ebenkof.

\section{CORNACE円.}

Cornus canadensis L. Sp. Pl. i, 118 (1753). 'Trpe locality, Canada.

Khantaak Island, June 15 (No. 23); abundant in the deuse lowland wooks at the base of Momnt Tebenkof, ascending to an altitude of 100 meters. Mature fruit was collected August 27.

\section{CAPRIFOLIACE王.}

Sambucus racemosa L.Sp. Pl. i, 270 (1753). Type locality, Europe. Khantaak Island, June 15 (No. 2t). See page 329.

Viburnum pauciflorum Pylaie; Torr. aud Gr. Fl. ii, 17 (1811). The tspesprecimens Tere collected in Nerfoundland by Pylaie.

Khantaak Island, June 15 (No.22). Fruiting specimens were collected A ugust 27. For notes on distribution aud use, see page 329 .

\section{VALERIANACER.}

Valeriana sitchensis Bong. Veg. Sitch. 145 (1831). Type specimens from Sitka. 1)iseuchantment Bay, August 4 (No.87); abundant on sandy slopes near the beach, and rising to an altitude of 180 meters. 


\section{CARDUACEAE.}

Aster foliaceus Lindl.; DC. Prodr, v, 228 (1836). The type specimens were from Unalaska.

Khantaak Island, July 27 (No. 78), on a bluft along the western side of the island.

Erigeron salsuginosus (Richards.) Gray, Proc. Amer. Acad. xvi, 93 (1881); Aster salsuginosus Richards. App. Frankl. Journ. 748 (1823). 'Type locality, the Salt Plains in Athabasca.

Khantaak Island, June 27 (No. 46); common in openings in the forest.

Antennaria alpina (L.) Gaertn. Fruct. ii, 410 (1791); Gnaphalium alpinum L. Sp. P1. ii, 856 (1753). Type specimens from the Alps of Lapland and fowitzerland.

Disenchantment Bay, August 10 (No. 101); ranging from sea level to an altitude of 250 meters.

Antennaria margaritacea (L.) Hook. Fl. Bor. Amer. i, 329 (1834); Gnaphalinm margaritaceum L. Sp. Pl. ii, 850 (1753); dnaphatis margaritacea Benth. \& Hook. Gen. Pl. ii, 303 (1873). No more specific localities were assigned for the Limnean specimens than North America and Kamchatka.

Along the banks of a river flowing into Disenchantment Bay, at a point southeast of Haenke Island, Angust 11 (No. 106), iu sandy soil.

Achillea millefolium L. Sp. Pl. ii, 899 (1753). Type specimeus from Europe.

At Ocean Cape, July 18 (No. 69), abundant on the sandy beach; at Point Manby and in Disenchantment Bay, both along the beach aud on the hillsides to an altitudo of 135 moters. The specimens belong to the boreal type of the plant, which has a darker-colored involucre than the weed of more southern rauge.

Artemisia norvegica pacifica Gray, Syn. Fl. i, pt.ii, 371 (1884). Range given as from the Aretic coast to the Alentiau Islands, etc. The name of this plaut unquestionably must be changed.

Disenchantment Bay, August 8 (No. 93); abundant, occurring from sea level to an altitude of 200 meters. Some of the specimens are very large and robust, reaching $60 \mathrm{~cm}$. in height, the petioles of the basai leaves sometimes $25 \mathrm{~cm}$. long and their blades $13 \mathrm{~cm}$. Its place of growth, on a grassy bank near the beach, undoubtedly accounts for this unusual development.

Arnica latifolia Bong. Veg. Sitch. 147 (18:33). Type sperimen collected at Sitka by Mertens.

Yakutat Bay, near the Mission, July 30 (No. 79), and at Dalton Landing (No. 122); in the former locality common in open swampy places in the forest, in the latter growing in abundance among the sand dunes along the beach.

Tussilago frigida L. Sp. Pl. ii, 865 (1753). Type Iocality European.

Disenchantment Bay, August (No. 105); growing in wet, sheltered spots from sea level to an altitude of 75 meters. Our specimens, as well as others from Alaska, do not conform with the typical plant of Europe. The flowering stems reach $40 \mathrm{~cm}$. in height, and the petioles $25 \mathrm{~cm}$; while the leaf blades, which are usually more nearly reniform than deltoid, with sinuses reaching one-third or one-half tho way to the base, attain a breadth of $15 \mathrm{~cm}$. The ligules of the ray flowers are minute and inconspicuous in both kinds of anthodia.

Hieracium triste Willl.; Spreng. Syst. iii, 610 (1826). Type specimen from the Aleutian Islands.

Disenchantment Bay, August 12 (No. 107); at an altitucle of 1,000 meters. It occurred sparingly on crassy slopes from this altitude down to sea level, at the lower points bearing mature frnit.

Prenanthes alata (Hook.) Gray, Syn. Fl. i, pt. ii, 435 (1884); Nabalus alatus Hook. F1. Bor. Amer. i, 294, t. 102 (1834). Type locality, Fort Vancouver, Washington.

Disenchantment Bay, Angust 13 (No. 115); extending abundantly from an altitude of 650 meters down to 450 meters, and sparingly down to 150 meters. 


\section{CAMPANULACEZ⿱乛龰⿱一𫝀厶.}

Campanula rotundifolia alaskana Giray, Syı. Fl. ii, pt. i, 345, (18*6). The range given with the description is from the northern Alentian Islands to Kalliak and Sitka.

Disenchantment Bay, July 10 (No. 56) and August 10 (No. 102); the latter nearly past flowering. The namo here used ean not properly be applied to this plant under the present principles of nomenclature, but an examination of type specimens is necessary to ascertain its proper clesignation. No. 56 was found on the side of a steep, rocky bluff, about 25 kilometers north of the Mission. Where No. 102 was collected the species occurred abundantly on the grassy momtain slopes at an altitude of 350 to 675 meters.

\section{ERICACEA.}

Vaccinium ovalifolium Smith in Rees, Cyel, xxxvi (1819). Type specimen, "brought by Mr. Menzies from the west coast of North America."

At the Mission, May 31 (No. 8), The plant at this dato had nearly ceased bloomind. Mature fruit was collected August 27. For notes on the distribution aud uses of this plant, sce patge 329 .

Cassiope stelleriana (Pall.) DC. Jrorlr. vii, 611 (1839); Indromedte stelleriana Pall. Fl. Ross. ii, 58 t. $7 \pm$ t. 2(1790).

Disenchantment Bay, August 12 (No. 110); occurring at an altitude of 300 to 1,000 meters. On the summits of the mountains it is often the only plant to be found. "The thick leaves of this plant have thin edges, which character, as is suggested by their position in unfolding, may be due to tho pressure of the party in the bud.

Bryanthus glanduliflorus (Hook.) (iray, I'roe. Amer. Acaul. vii, $36 \times(186 \AA)$; Menziesia glanduliflorus Hook. Fl. Bor. Amer. ii, 40, t. 132 (1831). Typo specimens collected by Drummond in the alpine woods and mountains north of the Smoking River.

Disenchantment Bay, August 12 (No, 109); on the mountaius at the altitude of from 350 to 1,000 meters. 'The leaves of theso dlaskan specimens, which seem to be from the highest latitule in which the species has ever beren fouml, are thmmer and more serrate than in specimens from the southern portion of the range of the species. The densely glantular, hirsute corollit and calyx, the short-pilose but not glaudular filaments, and the lemon-yellow color of the corolla, distinguish it from the related species. The serrations of the leaves are tipped when young with glands which, like those of the calyx and corolla, afford a resinous-glandular protective covering for the exposed nascent parts of the plant.

Menziesia ferruginea Smith, Ic. Iued. t. 56 (1791).

Khantaak Island, June 10 (No. 26); common in the lowland forests on the mainland and extending to 550 meters on Mount Tebenkof. The filaments 11 these specimens are conspicuously short-pilose near the base.

Pyrola minor L. Sp. Pl. i, 396 (1753). Type locality European.

Disenchantment Bay, Angust 14 (No. 86); foumb at only a single point, in the shate of a clump of alders near the beach.

Pyrola secunda L. Sp. Pl. i, 396 (1753). 'Type locality Europenn.

On the eastern shore of Yakutat Bay about 30 kilometers north of the Mission, July 14 (No. 57). It was found, but not frequently, at several points in the forest area growing in the moist moss.

Moneses uniflora (L.) Gray, Man. 273 (1818); Pyrola uniflora I. Sp. Pl. i, 397. Type locality Luropean.

Ocean Cape, July 9 ( No. 54), growing in the moss of a deuse forest, and in the mainland forest near Mount T'ebenkof. 


\section{4}

PRIMULACE更.

Trientalis europæa arctica (Fisch.) Ledeb. Fl. Ross. iii, 25 (1847); T. arefica Fisch.; Hook. Fl. Bor. Amer. i, 121 (1830). The range given with the original description is from Sandy Bay, in Clarence Straits, to Uualaska, and in Kamchatka.

Between the Mission and Cape Phipps, June $1(\mathrm{No}, 10)$; of frequent oceurrence in the spruce forest.

Glaux maritima L. Sp. Pl. i, 207 (1753). 'Type locality Europe.

On the mainland near the Mission, June 19 (No. 32); growing in patehes on the beach just above the line of high tide. It oceurred also on Khantaak Island at the head of Port Mulgrave.

\section{GENTIANACE王.}

Gentiana amarella L. Sp. Pl. i, 230 (1753). Type specimens from Europe.

Cape Phipps, July 23 (No.72), and Disenchantment Bay, August 11 (No. 104); at both points growing on the beach. Two forms are represented in these tro numbers, the best disposal of which, in the present state of our knowledge concerning the varieties of $G$. amarella, is to refer them to that species withont a varietal ilesignation. No. 72 has purplish foliage and stem, blue flowers, and a deeply cleft calyx, the narrow lobes of which are not more than one-half as long as tho corolla. No. 104. while very similar in form and size, has green herbage, yellow flowers, and a calyx with more foliaceous divisions, the larger commonly two-thirds to three-fourths as long as the corolla.

Gentiana platypetala Griseb. Gent. 191 (1839). The type specimens were collecterl on the island of Sitka during the second expedition of Kotzebue in the early part of the present century, and none have been reported since.

Disenchantment Bay, August 12 (No. 108). It has heen impossible to compare ours with the original specimens, yet from Grisebach's description we appear to have the same plant. It closely resenbles small specimens of $G$. calycosa, the stems being 15 to $22 \mathrm{~cm}$. high and bearing 6 to 10 pairs of ovate-oblong, obtuse or biuntly acute leaves. Each stem is terminated by a single sessile flower iuvolucrately surrounded by 2 or 3 pairs of leaves, the inner reduced. The calyx, which is about one-half as long as the tube of the campanulate blue corolla, has a spathaceous membranaceous tube 10 to $14 \mathrm{~mm}$. long, which usually spreads open along two opposite lines nearly to the base, the free margius being thin, searions, and apparently not torn. The calyx lobes proper are minute, lanceolate, acute, herbaceons organs abont $3 \mathrm{~mm}$. long. 'Ihe corolla lobes are couspicuously narrower at their insertion, broader than long, and abruptly acuminate, while the plaits in the sinuses are triangular, broader than ligh, and acute or emarginate.

Menyanthes trifoliata L. Sp. Pl. i, 145 (1753). Type locality Enropean.

Khantak Island, June 20 (No. 39); common in fresh-water ponds, growing both in the water aud on the adjacent wet soil.

\section{HYDROPHYLLACEAE.}

Romanzoffia sitchensis Bong. Veg. Sitch. 158 (1831). 'Type locality, Sitka.

Near Dalton Landing, August 1.5 (No. 123), growing among shaded rockis in a canyon leading from the St. Elias range. This plant so closely resembles a small saxifrage, Saxifraya nudicaulis for example, that a critical look at the corolla is necessary to distinguish it. Wen the thickened bases of the petioles and the two divergent carpels of the mature iruit precisely simulate those of certain saxifrages, yet they have the most widely different genetic relation. 


\section{BORAGINACE丑.}

Pneumaria maritima (L.) Hill, V'eg. Syst. vii, 40 (1764); I'ulmonariu marilima L. Sp. Pl. i, 136 (1753). Type locality, the sandy beaches of England.

On the west side of Yakutat Bay, about 10 kilometers north of Point Manby, Juno 28 (No. 50). Around Disenchantment Bay, also, the plant is common, and, as at the other locality, confined to the sandy beach.

\section{SCROPHULARIACEAE.}

Mimulus langsdorfii Domn; Sims, Bot. Mag. t. 1501 (1812). Description drawn from specinens grown in the Botanie (iarden at Cambridge, England, the seed coming "from Unashka [Cnalaska], one of the Fox Islaurls." This is the Himulus Tuteus of most American authors.

On the east side of Yakutat Jay, 26 kilometers north of the Mission, July 14 (No. $55)$, along a stream in dense woods; and again on a small stream emptying into Disenchantment Bay.

Veronica alpina L. Sp. Pl. i, 11 (1753). 'Type locality European.

Disenchantment Bay, August 9 (No.97), near a water ronrse; foumd but sparingly.

Castilleja miniata Dougl.; Hook. Fl. Bor. Amer. ii, 106 (1ミ38). Type specimens from the Blue Mrountains of Oregon.

On a saudy point at the mouth of the Ankow River, June 13 (No. 21), and in 1)is enchantment Bay, Angust 3 (No.82); the former with jellowish, the latter with red bracts. Tho plant is alundant in the valleys and lowlands about yukntat bay, and occurs occasionally up to an altitule of 550 meters.

Castilleja parviflora Bong. Veg. Nitelh. 1.8 (1831). Type specimens collected near Sitka.

Disenchantment Bay, August 5 (No. 89); found in but one place, on the southern slope of a mountain, abont 600 meters above the sea. These specimens were thus identified by the late Mr. H. E. Seaton.

Euphrasia officinalis L. Sp. Pl, ii, 604 (1753). 'T'spe specimens from Europe.

Dalton Landing, August 15 (No. 125); common in sandy soil of the beach. The specimens have less spinescent leaves and smaller thowers than the typical European plant.

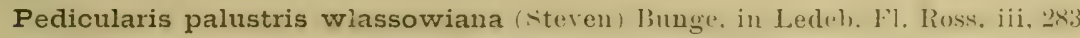
(1847); P. vlassowiana Steven, Mon. Pedic, 27, t. 9, fig. 1 (1822).

At the entrance of. Disenchantment Bay, July 24 (No. 75); frrowing along a sandy beach just above the line of high tide. The lower lip in these specimens is unusually short, not more than one-lialf as long as the galea.

Pedicularis sudetica Willd. Sp. Pl. iii, 209 (1800). Lescribel from plants collected in the Suldetic Mountains aud in Siberia.

Disenchantment Bay, Angust 9 (No.98); from sea level to an altitude of 120 meters.

Rhinanthus crista-galli L. Sp. Pl. ii, 603 (1753). Type locality wuropean.

Ocean Cape, July 18 (No. 68), and at Daltou Landing; growing in both stations on the sandy beach.

\section{POLYGONACEX.}

Polygonum viviparum L. Sp. Pl. i, 360 (1753). 'Type locality, Europeau.

On a bluff along the Ankow River, abont 10 kilometers above its mouth, July 16 (No. 65), and on the shores of Disenchantment Bay, 200 meters above the sea.

\section{FAGACEA.}

Alnus rubra Bong. Veg. Sitch., 162 (1831). The trpe specimen was collected at Sitka by Mertens.

Khantaak Island, Marg 27 (No.3). For the distribution of this plant, the red alder, see page 328. 


\section{SALICACEA.}

Salix arctica Pall. Fl. Ross, i, pt. ii, 86 (1788). Type locality “ in plaga aretica muscosa nuda secundum Sinum Obensein et versus glacialem Oceanum."

Disenchantment Iay, Angust 13 (No. 117). This willow, according to Mr. Funston's notes, is commou on the rocky mountaiu slopes about Disenchantment Bay, extending from sea level to the limit of vegetation. These specimens have obovate to orbicular, glabrons, reticulated leaves, glaucous beneath, rounded at the base, the blades of the larger ones 2 to $2.5 \mathrm{~cm}$. long. They bear mature fruit, the capsules glabrous. This form of Salix aretica is not known in the United States proper. Onr specimens have a short, thick, woods trunk, often $1 \mathrm{~cm}$. in diameter and two to three times as long, scarcely rising above the surface of the ground. From this trumk arise lateral l,ranches 10 to $30 \mathrm{~cm}$. in length, which retain their vitality only a few jears, spreading on the ground and ascending to the height of a few centimeters. The trunk is firmly fixed in the ground by means of stont roots.

Salix barclayi Auders. Proc. Amer. Acad. iv, 66 (1858). The type specimens were collected on Kadiak Island by Barclay.

Khantaak Island, May 30 (No, 6). For notes on this speecies, see page 328.

\section{ORCHIDACEA.}

Habenaria bracteata (Willd.) I. Br.; Ait. Hort. Kew. ed. 2, v, 192 (1813); Orchis bracteata Willd. Sp. Pl. iv, 34 (1805). Type specimen from Pennsylvania.

Disenchantment Bay, August 12 (No. 112). Scattered specimens were found from sea level to an altitude of more than 1,000 meters.

Habenaria dilatata (Pnrsh) Hook. Exot. Fl. ii, 95 (1825); Orchis dilatata Pursh, Fl, ii, 588 (1814). Type specimen from Labrador.

Along the Aukow River, near Ocean Cape, July 1 (No. 52). The plant grows in moist, shated parts of the forest region; and its suow-white flowers, according to Ir. Funston's observations, are very fragrant. Determinell by Thomas Morong.

Habenaria hyperborea (L.) R. Br.; Ait. Hort. Kew. v, 193 (1813); Orchis hyperborea L. Mant. i, 121 (1767).

Along the Ankow River, abont 10 kilometers above its mouth, July 16 (No. 64); abundant in fresh-water swamps. Determined by Thomas Morong.

\section{IRIDACEAE.}

Iris setosa Pall. ; Link, Jahresb. i, pt. iii, 71 (1841).

At the month of the Anlsow River, July 3 (No. 53), in sandy soil near a fresh-water pond. The Inclians are said to use the rootstock as a medicinal charm.

\section{LILIACEA.}

Streptopus amplexifolius (L.) Lam. \& DC. F'l. Franc, iii, 174 (1805); Truluria amplexifolic L. Sp. Pl. i, 304 (1753). Typo locality, Luropean.

About 25 kilometers north of the Mission, July 14 (No.61); common in the dense woods, and on Mount Tebeuk of found at the altitude of 180 meters. Fruiting specimens were collected on Khantaak Island, August 27.

Fritillaria camschatcensis (L.) Ker, Bot, Mag. under t. 1216 (1809); Lilium camschatcensis L. Sp. Pl. i, 303 (1753). Typo locality, Kamchatka.

Khantak Islaucl, June 20 (No.38). It occurs in openings throughout the lowland forest area in the vicinity of Yakutat Bay, ascending on Mount Tebenkof to an altitude of 900 meters. The use of this plant for food is recorded in Hooker's Flora Boreali-Americana, p. 181, as follows: "Voyagers to Kantschatka (where this species seems more abuudant than on the American coast) bring home small, white, granulated esculent roots, dried on strings. These are the bitter tubers of this Fritillary, 
which are also copiously eaten by the Inclians of Stikine, and known by the names of foch or $\mathrm{N}$. IW. lice; but Mr. Toline says they are bitter and nauseous." For the use of the plant among the Thlinkets, see page 330.

Tofieldia glutinosa (Michx.) I'ers. Syn. i, 399 (180.5); Vurlhecinm glutinosum Michx. Fl. i, 210 (1803). 'Type specimen collecter between ( nebee and Lako Mistassinie.

Khantak Island, Juwe 27 (No.47), along the margin of a fresh-water marsh.

\section{JUNCACE坐.}

Juncus falcatus alaskensis var. nov, ; probably $J$, fulcalus silehensis Buch. Monog. Junc. 428 (1890), not $J$. areticus sitehensis Engelm. (1866). 'Typo specimen in the United States National Herbarium, collected July 18, 1892, at Ocean Cape, Yakutat Bay, Alaska, by Frederick lunston (No. 67), growing in openings in the forest.

In the typical form of the species, which was originally collected at Monterey, California, and which scems to range as far northward as Puget Sonnd, tho styles are loug, the stigmas conspicuously exserted, and tho antliers much longer than their filaments, as in J. orthophyllus, bnt specimens collected at varions points from Yakutat Bay, Alaska, to the Alentiau Islands have a very short, thick style, and anthers little longer than their filaments. No fruiting specimens havo been seen, but the plant is doubtless the samo as Dr. Buchenau's varicty sitchensis, which was described, presumably from Alaskan specimens, as having a retuse olıcorilate capsule insteal of the obtuse ovate one of the type form. Tho plant occurs on the Aleutian islands, Atka and Unalaska, on the Shumagin Islands, at Yakutat Bay, and perhaps firther sonthward along the Alaskan coast.

Juncoides campestre sudeticum (Willd.) Coville, Contr. Iiat. Ilerb. ir, 208 (1893); Juncus sudeticus Willd. Sp. Pl.ii, 221 (1799); Luzula cempestris sudctica Celakovsky, Prodr. Fl. Bohm. 749 (1881). 'Type locality, the summit of' the Sudetic Monutains, of Silesia.

Knight Island, Juno 18 (No.28), growing on bare, well-drained sandy points.

\section{CYPERACE王.}

Eleocharis watsoni Babb. Ann. \& Mag. Nat. Hist. ser. 2, x, 20 (1852). 'Type specimen collected on tho seacoast of Seotland, near Tayauloan, Argyleshire.

Along the Aukow River, August 28 (No. 135); abundant along the margins of lagoons and fresh-water swamps. Mr. C. I3. Clarke ${ }^{1}$ has disposed of this species as a variety, watsoni, of $E$. palustris; but if our specimens are fairly representative of the plant, it appears much more sitisfuctory to treat it as a distinct species. They have culms 20 to $40 \mathrm{~cm}$. high, spikes at maturity 4 to $6 \mathrm{~mm}$. in diameter and 7 to $15 \mathrm{~mm}$. long, bracts of the spike black, with hyaline margins, and setio equaling the nutlet. The plant was identified by Dr. N. L. Britton.

Carex decidua ${ }^{2}$ Boott, Proc. Liun. Soe. i, 255 (1845). Type specimens from the Falkland Islands and from Port Famine, Straits of Magellan.

On the Ankow River, August 28 (No. 134); common in fresh-water swamps and along the edges of lagoons.

Carex festiva pachystachya Bailey, Mem. 'Torr. Club, i, 51 (1889).

Mainland, near Mission, Yakutat Bay, June 19 (No. 30); found wherever there is no shade. Common on the Ankow.

Carex limosa stygia (Fries) Bailey, Proc. Amer. Acad. xxii, 95 (1887); C. stygia Fries, Mant. iii, 141 (1842).

Knight Island, June 18 (No. 27); common along the edges of fresh-water ponds on the mainland and islands of the bay.

${ }^{1}$ Journal of Botany, xxy, 268 (1887).

2 The specimens of Carex were determined by I'rofessor L. H. Bailey. 


\section{POACE 互?}

Savastana odorata (L.) Scribn. Mem. Torr. Club, $\nabla, 34$ (1894); Holens odorutus L. Sp. Pl. ii, 108 (1753); Hierochloa borealis Roem. \& Schult. Syst.ii, 513 (1817). Type specimeus from Europe.

Khautak Island, June 20 (No. 36); found along the edges of bluffs about 6 meters above sea level.

Phleum alpinum L. Sp. Pl. i, 59 (1753). Type specimens from Europe.

On dry saud bars along streams; from sea level to 60 meters elevation. Abundant at Dalton Landiug, Angust 16 (No. 119); a few scattering specimens on Khantaak Island.

Agrostis exarata Triu. Diss. i, 207 (1824). Type locality, Unalaska.

Growing in seattered clumps on dry sand bars along suall rivers which empty into the sea. Disenchantment Bay, August 17 (No. 118); from sea level to 60 meters elevation.

Calamagrostis langsdorffi (Link.) Trin. Gr. Uuitl. 225 (1824); Amundo langsdorffii Link, Enum. i, 74 (1821). Type localit5, Siberia.

Ankow River, August 28 (No. 136); found generally along the beach near the edge of the forest, and on bluffs near the rivers.

Deschampsia cæspitosa (L.) Beauv. Agrost. 91 (1812); lira caspitosa L., Sp. Pl. i, 64 (1753). Type specimen from Europe.

Yakutat Bay, Angust 27 (No. 133); found everywhere in the vicinity of Yakutat Bay, often in great abundance. It occupies all the open, but not srvampy, spaces in the forests, and is found in abundance on the bluff's near the seashore and on the southern slope of Mount Tebenkof, to an altitude of 525 meters.

Deschampsia cæespitosa longiflora (Triu.) Vasey, Descr. Cat. Gr. 29 (1883); Aira crespitosa Tongiflora T'rin; Thurb. Bot. Wilkes Exped. xrii, 487 (1873-74). Type locality; "Nisqually and the north branch of the Columbia."

Disenchantment Bay, August 12 (No. 111); found in large quantities on the slopes of monntaius, at from 250 to 775 meters altitude, between the upper limit of red alder and the lower limit of summer snow, where it gives the mountains their lightgreen color. Some iracts of hundreds of acres of mountain slope are covered with it, to the exclusion of all other vegetation. It is not found in the forest country.

Poa alpina L. Sp. Pl. i, 67 (1753). Type specimen from Europe.

Dalton Landing, August 15 (No. 127); growing abundantly in small clusters on dry sand bars near Dalton Creek; also found near Cape Manby.

Poa glumaris Trin. Mem. Acal. St. Petersb. ser.6, i, 379 (1831). Trpe locality, Arctic Siberia.

Khantaak Island, Augast 29 (No. 137); common on gravelly beaches out of reach of high tides.

Puccinellia maritima (Huds.) Parl. Fl. Ital. i, 370 (1818); Poa maritima Huds. Fl. Angl. 42 (1762).

On the mainland near the Mission, at sea level; also on the beach at the base of Momt Tebenkof, June 21 (No.31); found only near the beach, where it grows in dense clumps; not common.

Elymus arenarius L. Sp. Pl. i, 83 (1753). 'Type specimen from Europe.

Near the Mission, August 29 (No, 140); abundant along sandy beaches, but found only near the sea. The thick culms play an important part in the basket making of the Thlinket Indians. When green they are cut, stripped of leaves, and dried near a fire. They are then used to form the uprights or framework around which are woven split spruce roots.

${ }^{1}$ Determined by the late Dr. George Vasey. 
PINACEP.

Picea sitchensis (Bong.) Carr. Trait. ('on. 260 (1855); Pinus sitchensis l3ong. Ten. Sitch. 161 (1831). Type specimen from Sitka.

Khantaak Island, Angust 27 (No. 131). The specimens hear well-developerl cones with vearly mature seeds. For the distribution and uses of the tree, see pages 328 and 334 .

Tsuga mertensiana (Bong.) Carr. 'Trait. Con. ex. 2, 250 (1867); Pinus mertensiana Bong. Veg. Sitch. 163 (1831). 'Type specimens collected at Sitki by Mertens.

Yakntat Bay, August 27 (No. 132). For notes on this tree, see page 328.

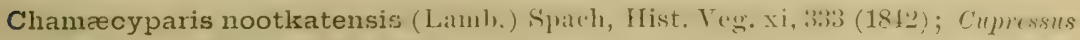
nootiatensis Lamb. Pin. ii, 18 (1824).

Khantaak Island, September' (No. 147). 'The specimens bear mature cones with fully grown sects, in many cases capable of germination. Only a single individual of this, tho Sitka cypress, was seen by Mr. linston in the territory that he trayersed. The tree does not follow in its range the same course as l'icen sitehensis, but in the southern portion of its range, in Oregon, is found remoto from the coast in the region of the Cascade Mountains.

\section{LYCOPODIACEAE.}

Lycopodium alpinum L. Sp. Pl. ii, 111)! (1753). 'I'ype locality European.

Growing in abundance, but at only ono place, on the bleak summit of a mountain 1,175 meters high, on the mainland sonthenst of IIaenke Island. Collected. August 13 (No. 113). At the base of some of the branches the complanate character of the stem and leaves is very marked, but in most parts of the plant this character is not seen.

Lycopodium annotinum L. Sp. Pl. ii, 1103 (1753). 'I'y pe locality European.

Near tho Mission, Angust 29 (No.139); abundant throughout tho lowland forest, growing ou decayed logs and in other similar soil.

\section{EQUISETACER.}

Equisetum variegatum Schleich. Cat. Pl. Helv. ed. 2, 27 (1807).

Khantaak Island, Augnst 30 (No. 142); common near the fresh-water swamps. Determined by L. M. Underwood.

\section{POLYPODIACEAE.}

Polypodium vulgare L. Sp. Pl. ii, 1085 (1753). 'Tรpe locality European.

Near the Mission, June 6 (No.13). The species is common throughont the forested area.

Cryptogramme acrostichoides R. Br.; Richards. Ap1). Frankl. Journ. 754 (182:3). The plant is more fully described in Brown's Addenda to the same work (p.767), where it is stated that the specimens were foumd by Menzies at Nootka Sound, Vancouver Island.

Dalton Landing, August 16 (No. 129); abundant among rocks.

Dryopteris spinulosa (Ketz.) Kuntze, Rrv. Gen. Pl. ii, \&10 (1891); I'olypodium spinulosum Retz. Fil. Scaud. ed.2, 250 (1795); Aspidium spinulusum Swartz; Schrad. Journ. Bot. ii, 38 (1800).

Near the Mission, June 19 (No.33). The sporangia are immature at this season. This ferm grows in the greatest profusion in the damp mossy woods about the Mission. On Mount Tebenkof, up to an altitude of 600 meters, certain areas were deusely covered with the plant.

Phegopteris dryopteris (L.) Feo, Gen. Fil. 24:3 (1850-185:); P'olypolium dryopteris L. Sp. Pl, ii, 1093 (1753). Type specimen from Europe. 
Near the Mrission, August 29 (No. 138). This fern grows in the greatest profusion in the spruce ferest of the lowlands ahont Yakntat Bay. On Mount Tebenkof it was found at an altitude of 380 meters.

Dryopteris lonchitis (L.) Kuntze, Rer. Gen. Pl. ii, 813 (1891); Polypodium lonchitis L. Sp. Pl. ii, 1088 (1753); Aspidium Tonchitis Swartz; Schrad. Journ. Bot. ii, 38 (1800). Type locality, the mountains of Europe.

Near the cabin, about 3 kilometers from Dalton Landing, August 15 (No. 126). Only one specimen was seen.

Cystopteris fragilis (L.) Bernh. Neues Journ. Bot. i, pt. ii, 26 (1806); Polyportium fragile L. Sp. Pl. ii, 1091 (1753). Type specimens from Europe.

Disenchantment Bay, August 14 (No. 120); found sparingly on the cliffs near the beach. Determined by L. M. Underwood.

\section{BRYACE王.'}

Polytrichum attenuatum Menz.; $P$. formosum Ifedw. Khantaak Island and mainland near the Mission (No. 17); common around the bases of trees and on decaying logs.

Polytrichum urnigerum L.; Pogonatum urnigerum Drum. Collecterl with the preceding (No. 152).

Astrophyllum punctatum (L.) Lindb, Mnium punclatum Hedw. Khantaak Island (Nos. 62 and 145); on decaying tree trunks, in slatded places.

Dicranum fragilifolium Lindb. Khantaak Island (No. 154); growing on decaying treo trunks.

Dicranum fuscescens Turn. Khantaak Island (No. 149); common on the bark of Aluus rubra.

Dicranum majus Turn. In woods on Khantaak Island (No 157).

Ceratodon purpureus (L.) Brid. Khantaak Island (No. 159).

Ulota barclayi Mitt. Khantaak Island (No. 158); on the bark of Alnus rubra.

Climacium ruthenicum Lindb. Khantak Island (No. 153).

Brachythecium letum (Brid.) Bruch \& Schimp. : Hypmm lifum Bri木. Khantaak Island (No. 156).

Hylocomium loreum (L.) Bruch of Schimp. ; Iymum loreum I. Kihantaak Islind (No. 146). Growing with Hylocomium squarrosum.

Hylocomium proliferum (L.) Lindb.; Hypnum splendens Hedw. Common in the woods on Khantaak Island (No. 148).

Hylocomium squarrosum (L.) Brtch \& Schimp"; H!lpmum squarrosum L. Ǐhantaak Island (No. 155). This moss is abundant in the forests around Yakutat Bay, growing ou tree trunks and stumps. The highest proint at which it was noted was 150 meters above sea level on the sille of Mount Tebenkof.

Hypnum arcuatum Lindb. Khantaak Island (No. 160); growing with Hylocomium proliferum.

Hypnum circinale Ilook. Khantaak Islaud (No. 150); growing on decaying logs.

Hypnum uncinatum Hedw. Khantaak Island (No. 144): growing on decaring tree trunks.

\section{SPHAGNACER:?}

Sphagnum squarrosum semisquarrosum liısis. Khantaak Island (No. 141). This moss grows in abmelance along the borders of bogs and swamps, both on the island and on the mainland.

${ }^{1}$ Determinerl by .T. M. Holzinger.

2 Determined by Dr. Christian Warnstort. 


\section{JUNGERMANNIACE A9.}

Blepharostoma trichophyllum (L。) Dum. Near lakutat Bay (No. 161). Cephalozia divaricata (Sm.) Dum. Near Yakutat Bay (No. 162).

Cephalozia multiflora Spruce. Near Yakutat Bay (No. 163).

Frullania nisquallensis Sulliy. Near Yakutat Bay (No. 164).

Kantia trichomanis (L.) S. F. Gray. Near Yakutat Bay (No. 165).

Lepidozia reptans (L.) Dum. Near Yakutat Bay (No. 166).

Plagiochila asplenioides (L.) Dum. Near Yakntat Bay (No. 167).

Radula krausei Steph. Near lakutat bay (No, 168).

${ }^{1}$ Anong the mosses collecter by Mr. Funston were detected several fragments of Hepratice, which have been determined ly Mr. A. Wr. Evans. 


\section{LIST OF SPECINIENS.}

1. Lubus spectabilis Pursh.

2. Fragaria chiloeusis (L.) Lam.

3. Alnus rubra Bong.

4. Caltha palustris $\mathrm{L}$.

5. Ribes laxillorum Pursh.

6. Salix barclayı Anders.

7. Cardamino oligosperma Nutt.

8. Vaccinium ovalifolium Snith.

9. Rubus stellatus Smith.

レ- 10. Trientalis curopara arctien (Hook.) Fisch.

11. Coptis trifolia (L) Salisls.

12. Viola lanesclortii Eisch.

13. Polspodium vulgare $\mathrm{L}$.

14. Actrea spicati arguta (Nutt.) 'l'orr.

15. Arabis lirsuta (L.) Scop.

16. Tiarella trifoliata $\mathrm{L}$.

17. Polytrichum attenuatum Menz.

18. Arenaria laterifiora $L$.

19. A renaria lateritlora $L$.

20. Lathyrus maritimus (L.) 13igel.

21. Castilleja miniata Bentl..

22. Viunrum paucitorum PJlaie.

23. Cornus canadensis $\mathrm{L}$.

24. Sambicus racemosa L.

? 25. Geum macroplyyllum TVills.

26. Menziesia ferruginea Smith.

2 2-. Carex limosa stygia (Fries) Bailey.

29. Juncoides campestre sudeticum (TVilld.) Coville.

a 2!) Ranunculus nelsonii (DC.) Gray.

30. Carex festiva pachystachya Bailey.

31. Puccinellia maritima (Huds.) Parl.

32. Glaux maritima L.

33. Dryopteris spinulosa (Retz.) Kuntze.

34. Potentilla anserina $\mathrm{L}$.

35. Lupinus nootkatensis unalaskensis Wats.

36. Savastana odorata (L.) Scribn.

¿ 37 . A renaria peploides $L$.

38. Fritiliaria camschatcensis (L.) Ker.

$\checkmark 39$. Menyanthes trifoliata L.

40. Saxifraga punctata $L$.

41. Saxifraga mertensiana Bong.

42. Claytonia sibirica $\mathrm{L}$.

43. N jmphra polysepala (Engelm.) Greene.

14. Colopleurum gmelini (DC.) Ledeb.

45. Heraclem lanatum Michx.

46. Erigeron salsuginosus (Richards.) Gray.

צ 47. Totieldia glutinosa (Michx.) Pers.

45. Viola langsilorfii Fisch.

49. Epilobium latifolium $\mathrm{L}$.

50. Pneumaria maritima (L.) Hill.

51. Pliellopterus littoralis Schnidt.

7 52. Habenaria (lılatata (I'ursh) Hook.

53. Irís setosa Pall.
54 Moneses unitlora (L.) Gray.

55. Mimulus Intens $\mathrm{L}$.

.2 ×56. Campanula rotundifolia alaskara Gray.

57. Pyrola secunda $T_{\text {. }}$.

58. Ejilobium luteum Pursh.

59: Heuchera glabra Willd.

60: Saxifraga stellaris L.

61. 'Streptopus amplexifolius (L*) DC.

62. 'A strophyllum punctatum(L.) Lindb.

63.' Potentilla palustris (L.) Scop.

64. Habenaria hyperborea (L.) R. Iir.

Y 65. Polygonum viviparum $\mathbf{L}$.

66. Sanguisorba latifolia (Hook.) Cuville.

67. Juncus falcatus alaskensis Coville.

6s. Rhinanthus crista-galli $L$.

09. Achillea millefolium $\mathrm{L}$.

70. Ligusticum scothicum I.

71. Cicuta virosa $I$.

72. Gentiana amarella $\mathrm{L}$.

73. Selinum gmelini (Cham. \& Schlecht.) Kurtz.

74. Yiola glabella Nutt.

75. Pedicularis palustris wlassoviana (Steven) Bunge.

76. Circea alpina $\mathrm{L}$.

77. Lathyrus palustris L.

78. Aster foliaceus Linil.

79. Arnica latifolia Bong.

so. Epilobium palustre L.

? 81. Ranunculus reptans $\mathrm{L}$.

8.. Cadtilleia miniata (Benth.) Dougl.

83. Tellima grandifiora (Pursh) R. Br.

84. I rabis ly rata L.

$\checkmark 85$. Cerastium alpinum $\mathrm{L}$.

86. Pyrola minor $\mathrm{L}$.

( 88. Parnassia fimbriata Koenig.

8.. Valèriana sitchensis Bong.

89. Castilleja parviflora Bong.

90. Luetkea pectinata (Pursh) Tuntze.

91. Saxifraga bronchialis $\mathrm{L}$.

2 92. Sbrbus occidentalis (Wats.) Greene.

93. Ártemisia norregica pacifica Gray.

94. Potentilla villosa Pall.

95. Barbarea barbarea (L.) McMillan.

96. Draba stenoloba Ledeb.

97. Veronica alpina $L$.

98. Pedicularis sudetica Willd.

90. Ranunculus cooleya Vasey \& Rose.

100. Geranium erianthum DC.

101. Antennaria alpiua (L.) Gaertn.

102. Campanula rotundifolia alaskana Gray.

103. Potentilla villosa Pall.

S104. Gentiana amarella L.

105. Tussilago frigida $\mathrm{L}$

106. Antennaria margaritncea (L.) Hook. 
107. Hieracium tristo Willd.

108. Gentiana platy petala Griseb.

109. Bryanthus glanduliflorns (Hook.) Grar.

110. Cassiope stelleriana (P'all.) DC.

111. Deschampsia cespitosa longifora Trin.

112. Habenaria bracteata (Willd.) R. Br.

113. Lycopodium alpinum $\mathrm{J}$.

114. Anemone narcissitiora $\mathrm{L}$.

115. Prenanthes alata (Hook.) Gray.

116. Aconitum delphinifolium DC.

117. Salix arctica I'all.

118. Agrostis exarata Trin.

119. Phleum alpinum $\mathrm{L}$.

120. Cystopteris fragilis (L.) Terul.

121. Aquileria formosit Fisch.

122. Arnica latifolia Bong.

123. Romanzottia sitchensis Bong.

124. Potentilla procumbens (L.) Clairv.

125. Euphrasia officinalis L.

126. Dryopteris lonchitis (L.) Kuntze.

127. Ioa alpina $\mathrm{L}$.

128. Epilobium latifolium $\mathrm{L}_{\text {. }}$.

129. Cryptogramme aerostichoides $\mathrm{Ki} . \mathrm{Br}$.

130. Geum calthifolium Smith.

131. Picen sitcliensis (Bong.) Carr.

132. Tsuga mertensiana (Bong.) Carr.

133. Deschampsia exspitosa (I.) Beaur.

134. Carex decidua Boott.

135. Eleocharis watsoni Bahb.

136. Calamagrostis langadorfii (Link) 'Trin.

137. Poa glumaris 'Trin.

138. Phegopteris dryopteris (L.) Fee.

135. Lycopolium annotinum $\mathrm{I}$.

$5076-N o .6$
140. Elymus arenarius $\mathrm{L}$.

141. Sphagnum squarrosum semisquarrosum Riuss

142. Equisetum rariegatum Schleich.

143. Eehinopanax horridum Swith.

14. Hypum uncinatum Hedw.

145. Astrophyllum punctatum (L.) Liudu.

146. Hylocomium loreum (L.) Bruch \& Schimp.

147. Chamacy paris nootkatensis (Laub.) Spach.

148. Hylocomium proliferum (L.) Lindb.

149. Dicranum fuscescens Turn.

150. Hуриим circinale Hook.

151. Rubus pedatus Smith.

152. Polytrichum urnigerum $L$.

15:3. Climacium ruthenicum Lindb.

15t. Dicranum fragilifolium Linclb.

15.. Hylocomium squarrosum (L.) Bruch \& Schimp.

15f, Brachythecium letum (Bril.) Jruch \& sehimp.

1.7. Dicranum majus Turn.

155. Ulota barclayi Mitt.

159. Ceratodon purpureus (L.) Brid.

160. Hypnum arcuatum Lindb.

161. Blepharostoma trichophylium (L.) Dum.

162. Cephalozia divaricata (Sm.) Dum.

16:3. Cephalozia multiflora Spruce.

164. Frullania nisquallensis Sullix.

165. Kantia trichomanis (I.) S. F. Gray.

160. Lepidozia reptans (L.) I $12 m$.

16i. Plagiochila asplenioiles (I L.) Dum.

168. Iialula kransei Steph. 



\section{N DEX.}

\begin{tabular}{|c|c|c|c|}
\hline & & & \\
\hline n...................... & 342 & Echinopanax............... & \\
\hline 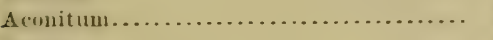 & 336 & leocharis ................... & \\
\hline 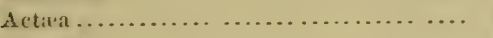 & 336 & & \\
\hline grustis .................................. & 348 & pilobinm ................ & \\
\hline 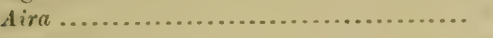 & 348 & quisetum................ & \\
\hline nus.................................. & 345 & rigreron ................... & \\
\hline halis................................ & $3+2$ & $u m \ldots . . . . . . . . .$. & \\
\hline omeda ........................... & $34: 3$ & & \\
\hline & $3: 35$ & $\cdots \cdots \cdots$ & \\
\hline 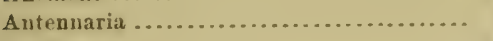 & 34 & a $\ldots \ldots \ldots \ldots \ldots \ldots$ & \\
\hline & & n.............. & \\
\hline 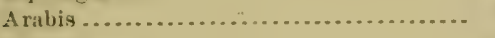 & 336 & & \\
\hline elica .......................... & 341 & ................. & \\
\hline & & n............... & \\
\hline & & (n............... & \\
\hline$\ldots \ldots \ldots \ldots \ldots \ldots \ldots \ldots \ldots \ldots \ldots \ldots \ldots$ & 342 & & \\
\hline$\ldots \ldots \ldots \ldots \ldots \ldots \ldots \ldots \ldots \ldots \ldots \ldots \ldots \ldots \ldots$ & 346 & 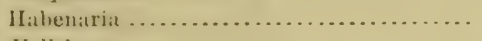 & \\
\hline n ......................... 349 &, 350 & $u s, \ldots \ldots \ldots \ldots \ldots \ldots \ldots \ldots \ldots \ldots \ldots \ldots \ldots \ldots$ & \\
\hline & 342 & im............................... & \\
\hline $11-2 \ldots$ & 350 & & \\
\hline$\ldots \ldots \ldots \ldots \ldots \ldots \ldots \ldots \ldots \ldots \ldots \ldots \ldots$ & $: 336$ & & \\
\hline n......................... & 35 & 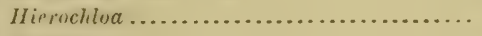 & \\
\hline n. & 35 & (n.......................... & \\
\hline$\ldots \ldots \ldots \ldots .343$ & 339 & t.......................... & \\
\hline n...................... & 34 & 然 & \\
\hline 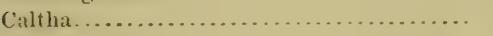 & 3: & 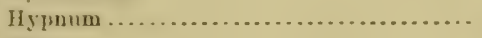 & \\
\hline & 34 & & \\
\hline$\cdots \cdots \cdots \cdots$ & 336 & 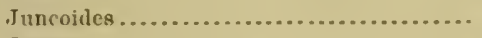 & \\
\hline ................... & 34 & & \\
\hline 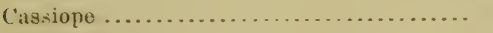 & 3. & (n...n. & \\
\hline & & a $\ldots \ldots \ldots \ldots \ldots \ldots \ldots \ldots \ldots$ & \\
\hline & 35 & (........................ & \\
\hline h & $3:$ & ... & \\
\hline$\ldots \ldots \ldots \ldots \ldots \ldots \ldots \ldots \ldots \ldots \ldots$ & & (n) & \\
\hline & & 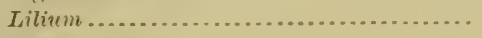 & \\
\hline & $3=$ & (n... & \\
\hline , & 3 & 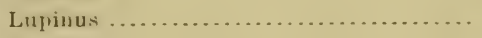 & \\
\hline$\ldots \ldots \ldots \ldots \ldots \ldots \ldots \ldots \ldots \ldots$ & & 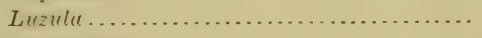 & \\
\hline n $\ldots \ldots \ldots \ldots \ldots \ldots \ldots \ldots \ldots \ldots \ldots \ldots \ldots \ldots \ldots \ldots$ & 35 & 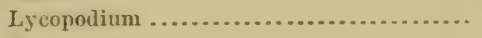 & \\
\hline (n... & & (3) & \\
\hline (......... & 33 & ( & \\
\hline ............. & 33 & ......... & \\
\hline .............. & 3. & 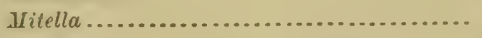 & \\
\hline 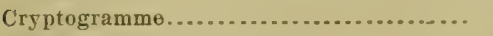 & 34 & 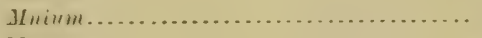 & \\
\hline & 34 & 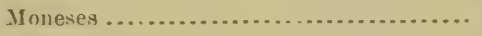 & \\
\hline , & 35 & ( & \\
\hline io & 34 & cium .............................. & \\
\hline & 35 & har .................................... & \\
\hline & 33 & haca............................. & \\
\hline 3 & & (n........................ & \\
\hline
\end{tabular}




\begin{tabular}{|c|c|c|c|}
\hline \multicolumn{2}{|c|}{ Page. } & \multicolumn{2}{|c|}{ Page. } \\
\hline Panax... & 341 & Romanzoftia........................... & 344 \\
\hline Paruassia ... & 340 & 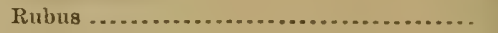 & 338 \\
\hline Pedicularis.. & 345 & 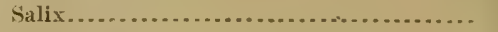 & 346 \\
\hline Phegopteris. & 349 & . Sambucus............................ & 341 \\
\hline Phellopterus &, 338 & Sanguisorba . . . & 339 \\
\hline Phleum ..... & $3+8$ & 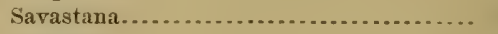 & 348 \\
\hline Picea....... & 349 & Saxifraga ........................... 338,339 & , 344 \\
\hline I'inus....... & 349 & 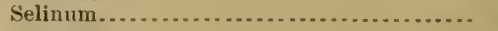 & 341 \\
\hline Pisum....... & 338 & Sibbaldia....... & 339 \\
\hline P'lagiochila.. & 351 & Sorbus .................................. & 339 \\
\hline I'neumaria.. & 345 & Sphagnum . . & 350 \\
\hline Poa ......... & 348 & Streptopus............................ & 346 \\
\hline Pogonatum. & 350 & Tellima....................... & 340 \\
\hline Polygonums. & 345 & 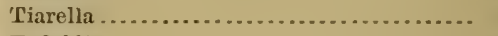 & 340 \\
\hline Polypodium. & 350 & 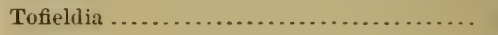 & 347 \\
\hline Polytrichum & 350 & 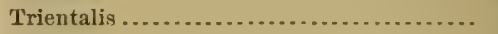 & 344 \\
\hline Potentilla ... & 339 & 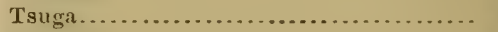 & 349 \\
\hline Poterium.... & 339 & 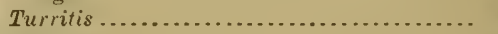 & 336 \\
\hline Prenanthes. & 342 & Tussilago & 342 \\
\hline Puecinellia.. & 348 & 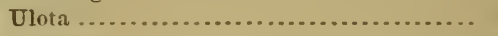 & 350 \\
\hline Pulmonaria. & 345 & Evularia ................................... & 346 \\
\hline Pyrola ....... & 313 & 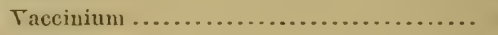 & 343 \\
\hline Pyrus...... & 339 & 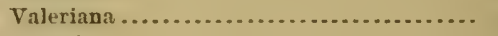 & 341 \\
\hline Radula...... & 351 & Veronica .............................. & 345 \\
\hline Rauunculus. & 335 & 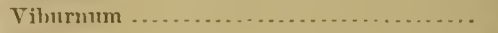 & 341 \\
\hline Rhinanthus. & 345 & Violit................................... & 337 \\
\hline liiless ....... & $\ddot{40}$ & & \\
\hline
\end{tabular}




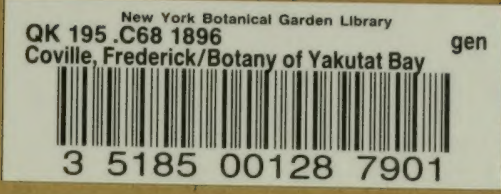

\section{IMAGED}



